\section{Calcium and Phosphorus Levels in Saliva are Influenced by Genetic Polymorphisms in Estrogen Receptor Alpha and Microrna 17}

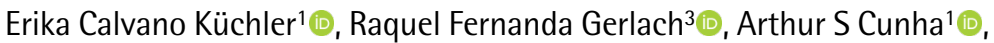
Lucas A Ramazzotto ${ }^{1}{ }^{\oplus}$, Paula Porto Spada ${ }^{2}{ }^{\circ}$, Paulo Nelson-Filho ${ }^{1} \odot$, Junia Ramos $^{3}$, Giovana Daniela Pecharki ${ }^{4}{ }^{\circ}$, Fernando Barbosa Jr ${ }^{5} \odot$, Alexandre

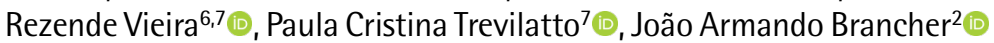

\begin{abstract}
Homeostasis between salivary calcium and phosphorus is important for maintaining oral health. The aim of this study was to evaluate if polymorphisms in ESR1 (Estrogen Receptor Alpha), ESR2 (Estrogen Receptor Beta) and miRNA17 (microRNA17) are associated with calcium and phosphorus levels in saliva. Saliva from 276 12-year-old children were collected by masticatory stimulation and calcium and phosphorus levels were determined by Mass Spectrometry. Genomic DNA was extracted from remaining saliva and genetic polymorphisms in ESR1 (rs12154178, rs1884051, rs9340799 and rs2234693), in ESR2 (rs4986938 and rs1256049) and in miRNA17 (rs4284505) were genotyped using TaqMan chemistry and a real-time PCR equipment. Statistical differences in genotype and allele distributions between 'low' and 'high' calcium and phosphorus levels were determined using chi-square or Fisher's exact tests. The analysis was also adjusted by sex (alpha of $5 \%$ ). ESR1 rs9340799 had the less common genotype associated with higher calcium levels $(p=0.03)$. The less common allele of ESR1 rs1884051 was associated with lower phosphorus levels $(p=0.005)$ and there was an excess of heterozygotes for miRNA17 rs4284505 among individuals with lower calcium levels $(p=0.002)$, both adjusted by sex. This study provides evidence that genetic polymorphisms in ESR1 and miRNA17 are involved in determining salivary calcium and phosphorus levels.
\end{abstract}

\author{
'Department of Pediatric Dentistry, \\ Ribeirão Preto Dental School, \\ USP - Universidade de São Paulo, \\ Ribeirão Preto, SP, Brazil \\ ${ }^{2}$ School of Health Sciences, UP - \\ Universidade Positivo, Curitiba, Brazil \\ ${ }^{3}$ Department of Morphology, \\ Physiology and Basic Pathology, \\ Ribeirão Preto Dental School, \\ USP - Universidade de São Paulo, \\ Ribeirão Preto, SP, Brazil \\ ${ }^{4}$ Department of Community Health, \\ UFPR - Universidade Federal \\ do Paraná, Curitiba, Brazil \\ ${ }^{5}$ Department of Clinical, Toxicological \\ and Bromatological Analysis, Faculty \\ of Pharmaceutical Sciences of \\ Ribeirao Preto, USP - Universidade \\ de São Paulo, Ribeirão Preto, Brazil \\ ${ }^{6}$ Department of Oral Biology, \\ University of Pittsburgh, \\ Pittsburgh, PA \\ ${ }^{7}$ Center for Health and Biological \\ Sciences, PUCPR - Pontifícia \\ Universidade Católica do \\ Paraná, Curitiba, Brazil
}

\begin{abstract}
Correspondence: João Brancher, Rua Professor Pedro Viriato Parigot de Souza, 5300, 81280-330 Curitba, PR, Brasil. E-mail: brancher.a@gmail.com

Key Words: Saliva, polymorphism, estrogen receptor, MicroRNA
\end{abstract}

\section{Introduction}

The relationship between calcium and phosphorus levels with estrogen is not a new concept and has been widely explored. Estrogen is one of the most widely known and discussed hormones. The term "estrogen" actually refers to a group of chemically similar hormones named estrone, estradiol and estriol. Estrogens play key roles in both male and female development, exerting a vast range of biological effects (1) including important effects on calcium and phosphorus homeostasis (2).

A negative whole-body calcium balance results from the lack of estrogen, which causes reduced calcium absorption in the gut and increased calcium excretion in the urine $(3,4)$. In addition, studies on the effect that hormone replacement therapy exerts on oral environment of menopausal women proposed that estrogen might have a biological role in the oral environment $(5,6)$.

Saliva is a biological fluid that provides electrolytes, including calcium and phosphorus, and proteins that interact to modulate oral $\mathrm{pH}$, balance the microbiota and regulate the process of hard dental tissues demineralization and remineralization (7). Salivary calcium is important for dental health (8), patients who have increased salivary inorganic calcium and phosphate have less caries (9). Two estrogens receptors (ER) mediate cellular signaling of estrogens: $E R \alpha$, coded by ESR1 gene, and ER $\beta$, codified by ESR2. Both ERs belong to the nuclear receptor family of transcription factors. Studies with knockout mice for Esr1, Esr2 and double knockout demonstrated that ER $\alpha$ and $E R \beta$ have distinct, nonredundant roles in the normal physiology (reviewed by Heldring et al. (1)). Another study demonstrated that buccal mucosa and salivary gland tissue contains ERs, which suggests that they might be estrogenresponsive tissues (6).

MicroRNAs (miRNAs) are a family of small, non-coding RNAs that regulate gene expression post-transcriptionally in a sequence-specific manner. Some miRNAs have been identified as ESR1 and ESR2 regulators. Moreover, the expression of some miRNAs, such as miRNA17, are modulated by estrogen (10), which might result in a relationship between this class of nucleic acids and calcium and phosphorus levels.

Here we report the evaluation of genetic polymorphisms in ESR1, ESR2 and miRNA17 and calcium and phosphorus levels of children's saliva.

\section{Material and Methods}

\section{Studied Population and Clinical Examination}

The Human Ethics Committee of the PUC-PR and the Pittsburgh Institutional Review Board approved this study. 
Informed written consent was obtained from the parents or legal guardians of the participants and age appropriate assent documents were used for all children.

Two hundred seventy-six 12-year-old biological unrelated children, 138 males and 138 females, from private and public schools of Curitiba-PR, Brazil, were included in this study. The exclusion criteria were individuals with syndrome and/or systemic illness, odontogenic pain, orthodontic appliances, occlusal splints, dental prostheses, severe facial or dental anomalies, with cognitive or behavioral problems, and speech disorders. The characteristics of this population were previously described (11).

\section{Saliva Collection and Measurements}

The method used for saliva collection involved mechanical masticatory stimulation using a piece of sterile rubber tourniquet with standardized size of $1.5 \mathrm{~cm}$. This rubber was masticated continuously by the patient for $6 \mathrm{~min}$. The saliva produced during the first minute of stimulation was discarded. During the following $5 \mathrm{~min}$, the patient expelled saliva into a sterilized universal collecting recipient that had been previously weighed using Marte analytical scales, model AL 500 (São Paulo, $\mathrm{SP}$, Brazil). Calcium and phosphorus levels in the saliva were determined at the Laboratory of Metals Toxicology, University of São Paulo at Ribeirão Preto (Brazil), by Inductively Coupled Plasma-Mass Spectrometry (ICP-MS).

The remaining saliva was used for genotyping analyses, in which the genomic DNA was extracted from the buccal cells at the Molecular Biology laboratory of Pontifical Catholic University of Paraná (Brazil) using an established protocol (12).

\section{Real Time Polymerase Chain-Reactions (PCR)}

Genetic polymorphisms were selected in ESR1, ESR2 and in miRNA17. miRNA17 was chosen for this study based on the fact that it is predicted to bind and modulate ESR1 expression, according to the miRBase database (http://www. mirbase.org). Also, miRNA17 have been demonstrated to be modulated by estrogen (10). Other important factor to select this miRNA beside the others predict to bind in ERs is the fact that miRNA17 presents a genetic polymorphism with a minor allele frequency higher than $10 \%$. The studied genetic polymorphisms are described in Table 1.

Genotyping assays were performed in Ribeirão Preto (Brazil) and in Pittsburgh (US) using the Taqman ${ }^{\mathrm{TM}}$ method for real-time PCR or conventional PCR with end-point analysis. The ABI PRISM ${ }^{\circledR} 7900 \mathrm{HT}$ Sequence Detection System (Applied Biosystems, Foster City, CA, USA) in the Molecular Biology laboratory at University of São Paulo was used to genotype the rs9340799, rs2234693, rs4986938, rs 1256049 and rs 4284505 polymorphisms. The QuantStudio
6 Flex (Applied Biosystems) at the Vieira Lab, University of Pittsburgh was used to genotype the rs12154178 and 1884051 polymorphisms. Taqman ${ }^{\text {TM }}$ probes were supplied by Applied Biosystems.

\section{Statistical Analysis}

Calcium and phosphorus levels were analyzed as dichotomous variables. Based in a method previously described (11), calcium and phosphorus levels were categorized as 'low' and 'high' according to the medium value of each variable. Children with salivary calcium levels above the median value (9.84 micrograms $/ \mathrm{ml}$ ) were included in the 'high salivary calcium group' and children with the calcium levels below this median were included in the 'low salivary calcium group'. Children with salivary phosphorus levels above the median value $(126.81 \mu \mathrm{g} / \mathrm{mL})$ were included in the 'high salivary phosphorus group' and children with the phosphorus levels below this median were included in the 'low salivary phosphorus group'.

Differences in genotype and allele distributions between groups were determined using chi-square or Fisher's exact tests. Haplotype analyses were done as implemented in the PLINK program (13). Hardy-Weinberg equilibrium was determined using the chi-square test within each genetic polymorphism.

The analysis was also adjusted by sex. An established alpha of $5 \%$ was used.

\section{Results}

The median (01-03) calcium level was $9.84 \mu \mathrm{g} / \mathrm{mL}$ (6.77-13.65). The median (01-03) phosphate level was $126.81 \mathrm{mcg} / \mathrm{ml}$ (109.32-149.47). Sex, ethnicity and age were not different between the individuals based on their calcium and phosphorus levels in saliva grouping ( $p>0.05$ ). All studied genetic polymorphisms were in Hardy-Weinberg equilibrium (data not shown).

Table 2 describes the genotype (in the additive model and in the additive model adjusted by the sex) between low and high calcium and phosphorus levels. For the genetic polymorphism rs9340799 in ESR1, the genotypes distributions between "Low" and "High" calcium levels were statistically significant associated in the both analysis, additive model and additive model adjusted by the gender ( $p=0.03$ and $p=0.005$, respectively). For the genetic polymorphism rs4284505 in miRNA17 the genotypes distributions between "Low" and "High" calcium levels were statistically significant associated in the both analysis, additive model and additive model adjusted by the gender ( $p=0.01$ and $p=0.002$, respectively).

In the allele distributions, only the genetic polymorphism rs1884051 in ESR1 presented a statistical association. The allele A was more frequent in the "High" phosphorus levels 
group (62.9\%), than in the "Low" phosphorus levels group $(79.6 \%)(p=0.001)$ (data not shown in the table).

Table 1. Description of the studied genetic variations

\begin{tabular}{|c|c|c|c|c|c|}
\hline Gene symbol & Gene name & Chromosome position & Polymorphism & Base change & Average heterozygosity $( \pm S E)$ \\
\hline \multirow{4}{*}{ ESR 1} & \multirow{4}{*}{$\begin{array}{c}\text { Estrogen Receptor } \\
\text { Alpha }\end{array}$} & \multirow{4}{*}{6} & rs 12154178 & $\mathrm{~A} / \mathrm{C}$ & $0.499+/-0.026$ \\
\hline & & & rs 1884051 & $\mathrm{~A} / \mathrm{G}$ & $0.500+/-0.009$ \\
\hline & & & rs9340799 $\psi$ & $\mathrm{A} / \mathrm{G}$ & $0.404+/-0.197$ \\
\hline & & & rs2234693\# & $\mathrm{C} / \mathrm{T}$ & $0.494+/-0.053$ \\
\hline \multirow[b]{2}{*}{ ESR2 } & \multirow{2}{*}{$\begin{array}{c}\text { Estrogen } \\
\text { Receptor Beta }\end{array}$} & \multirow[b]{2}{*}{14} & rs4986938 & $\mathrm{A} / \mathrm{G}$ & $0.433+/-0.170$ \\
\hline & & & rs 1256049 & $\mathrm{~A} / \mathrm{G}$ & $0.125+/-0.217$ \\
\hline miRNA17 & microRNA17 & 13 & rs4284505 & $\mathrm{A} / \mathrm{G}$ & $0.500+/-0.004$ \\
\hline
\end{tabular}

Obtained from databases: http://www.ncbi.nlm.nih.gov; SE = standard error. \#Also known as PvuII. $\psi$ Also known as XbaI.

Table 2. Genotype and allele distribution between the groups. Statistical association results in the additive model and in the additive model adjusted by the gender

\begin{tabular}{|c|c|c|c|c|c|c|c|c|}
\hline \multirow[b]{2}{*}{ Gene } & \multirow[b]{2}{*}{ rs\# } & \multirow{2}{*}{\multicolumn{2}{|c|}{$\begin{array}{c}\text { Calcium and } \\
\text { phosphorus levels }\end{array}$}} & \multicolumn{3}{|c|}{ Genotype (\%) } & \multicolumn{2}{|c|}{$p$ values } \\
\hline & & & & AA & $\mathrm{Aa}$ & аa & $\begin{array}{l}\text { Genotype in an } \\
\text { additive model }\end{array}$ & $\begin{array}{c}\text { Genotype } \\
\text { adjusted by sex }\end{array}$ \\
\hline \multirow{16}{*}{ ESR1 } & \multirow{4}{*}{ rs12154178 } & \multirow{2}{*}{ Calcium } & Low & $52(40.94)$ & $54(42.52)$ & $21(16.54)$ & \multirow{2}{*}{0.74} & \multirow{2}{*}{0.34} \\
\hline & & & High & $54(42.86)$ & $48(38.10)$ & $24(19.05)$ & & \\
\hline & & \multirow{2}{*}{ Phosphorus } & Low & $48(37.80)$ & $55(43.31)$ & $24(18.90)$ & \multirow{2}{*}{0.41} & \multirow{2}{*}{0.30} \\
\hline & & & High & $58(46.03)$ & $47(37.30)$ & $21(16.67)$ & & \\
\hline & \multirow{4}{*}{ rs 1884051} & \multirow{2}{*}{ Calcium } & Low & 59(43.38) & $58(42.65)$ & 19(13.97) & \multirow{2}{*}{0.70} & \multirow{2}{*}{0.61} \\
\hline & & & High & $64(47.41)$ & $56(41.48)$ & 15(11.11) & & \\
\hline & & \multirow{2}{*}{ Phosphorus } & Low & $55(40.74)$ & $60(44.44)$ & $20(14.81)$ & \multirow{2}{*}{0.22} & \multirow{2}{*}{0.17} \\
\hline & & & High & $69(50.36)$ & $54(39.42)$ & $14(10.22)$ & & \\
\hline & \multirow{4}{*}{ rs9340799 } & \multirow{2}{*}{ Calcium } & Low & $63(46.67)$ & $62(45.93)$ & $10(7.41)$ & \multirow{2}{*}{0.03} & \multirow{2}{*}{0.005} \\
\hline & & & High & 73(53.68) & $44(32.35)$ & 19(13.97) & & \\
\hline & & \multirow{2}{*}{ Phosphorus } & Low & $68(51.13)$ & $54(40.60)$ & 11(8.27) & \multirow{2}{*}{0.43} & \multirow{2}{*}{0.11} \\
\hline & & & High & $68(48.92)$ & $53(38.13)$ & $18(12.95)$ & & \\
\hline & \multirow{4}{*}{ rs2234693 } & \multirow{2}{*}{ Calcium } & Low & $17(12.50)$ & $75(55.15)$ & $44(32.35)$ & \multirow{2}{*}{0.45} & 0 \\
\hline & & & High & $18(13.24)$ & $65(47.79)$ & $53(38.97)$ & & 0.30 \\
\hline & & & Low & 15(111.19) & $72(53.73)$ & $47(35.07)$ & & \\
\hline & & 1 1105pinotus & High & $20(14.39)$ & $69(49.64)$ & $50(35.97)$ & 0.05 & 0.45 \\
\hline & & & Low & $53(39.26)$ & $69(51.11)$ & 13(9.63) & & \\
\hline & & Calcium & High & $56(41.18)$ & $69(50.74)$ & 11(8.09) & 0.87 & 0.89 \\
\hline & 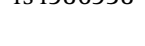 & Phocnhorus & Low & $58(43.28)$ & $64(47.76)$ & 12(8.96) & 0.55 & 0.51 \\
\hline & & r tiospiovius & High & $51(36.96)$ & $74(53.62)$ & $13(9.42)$ & 0.35 & 0.31 \\
\hline LJNL & & Colainn & Low & $115(93.50)$ & $6(4.88)$ & $2(1.63)$ & & \\
\hline & & Cartiunt & High & $113(94.17)$ & $7(5.83)$ & $0(0.00)$ & נכנ. & 0.12 \\
\hline & 151250049 & Dhor & Low & $111(94.07)$ & $6(5.08)$ & $1(0.85)$ & 800 & 70 \\
\hline & & rnosprotus & High & 118(93.65) & $7(5.56)$ & $1(0.79)$ & 0.88 & 0.18 \\
\hline & & Calcium & Low & $17(12.59)$ & $76(56.30)$ & $42(31.11)$ & $0.01 \#$ & $0002 \#$ \\
\hline & & Calcium & High & $28(20.74)$ & $53(39.26)$ & $54(40.00)$ & $0.01 \#$ & $0.002 \#$ \\
\hline 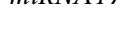 & 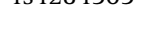 & & Low & 27(20.30) & $58(43.61)$ & 48(36.09) & & \\
\hline & & Pnosprorus & High & 19(13.77) & $71(51.45)$ & $48(34.78)$ & 0.26 & 0.28 \\
\hline
\end{tabular}

\#Indicates statistical significance $(\mathrm{p}<0.05)$. 
The haplotype analysis did not show any statistical significant difference depending on calcium or phosphorus levels ( $p>0.05)$.

\section{Discussion}

Salivary calcium and phosphorus play an important function to antagonize the solubility of the mineralized tissues of the mouth under acidic conditions (7). Therefore, we decided to evaluate whether genes involved in the estrogen pathway are associated with salivary calcium and phosphorus levels. In fact, dental remineralization depends on adequate saliva production and secretion that provides salivary calcium and phosphorus at appropriate levels (14).

In a previous study, we evaluated genetic polymorphisms in genes that are involved in enamel development and found an association between estrogen related receptor beta (ESRRB) and calcium levels in saliva (11). Although ESRRB has been previously suggested as playing a role in enamel development (15), it is also possible that the association between ESRRB and calcium level is due to the expression of this protein in salivary glands.

A clinical study demonstrated that therapy with estrogen hormone increased saliva production (16). Also, ovariectomized rats treated with estradiol returned the levels of muscarinic receptors to normal, indicating a protective role played by estrogen in saliva formation (17). Therefore, we decided to evaluate ESR1 and ESR2. Although salivary glands are not the traditional target for estrogens, their receptors are found in oral tissues (18). Based on the aggregate of these facts and on our results, it is possible to hypothesize that genetic polymorphisms in ERs are also involved in the inter-individual variation of calcium and phosphorus levels in saliva.

Estrogen can regulate the salivary rate by changes in the expression of muscarinic receptors (19), which are located in the acinar cells of salivary glands (20). In our study, we found that two ESR1 polymorphisms are associated with phosphorus levels (rs 1884051), and calcium levels (rs9340799), suggesting their potential as markers for dental caries susceptibility. Although salivary calcium and phosphorus imbalance may eventually be risk factor for sialolithiasis (21), in our sample none of the children presented an imbalance in these minerals.

It was found that miRNA17 was associated with calcium levels, also suggesting that this polymorphism is a potential marker for dental caries susceptibility. miRNAs are present in body fluids, including saliva, and are highly tissue specific, and potentially excellent biomarkers (22). Therefore, future studies should evaluate if the miRNA17 expression in saliva is a marker for salivary calcium levels and dental caries susceptibility.

Based on the results obtained, this study provides evidence that genetic polymorphisms in ESR1 is involved in salivary calcium and phosphorus levels and that miRNA17 is involved in calcium levels. The present study identified novel genes that should be evaluated in further caries researches. Additionally, these results have the potential to impact clinical practice in a near future allowing the clinicians to identify patients with higher risk of caries development.

\section{Resumo}

A homeostasia entre cálcio e fósforo salivares é importante para a manutenção da saúde bucal. 0 objetivo deste estudo foi avaliar se polimorfismos genéticos no receptor de estrógeno alfa (ESR1), receptor de estrógeno beta (ESR2) e no microRNA17 (microRNA17) estão associados com os níveis salivares de cálcio e fósforo. Saliva de 276 crianças com 12 anos de idade foi coletada com estímulo mastigatório e os níveis de cálcio e fósforo foram determinados por Espectrofotometria de Massa. 0 DNA genômico foi extraído da saliva remanescente e os polimorfismos genéticos em ESR1 (rs12154178, rs1884051, rs9340799 e rs2234693), em ESR2 (rs4986938 e rs1256049) e no miRNA17 (rs4284505) foram genotipados pela reação em cadeia da polimerase em tempo real utilizando sondas TaqMan. As diferenças estatísticas nas distribuições alélicas e genotípicas entre "baixo" e "alto" niveis de cálcio e fósforo foram determinadas usando os testes qui-quadrado e teste exato de Fisher. As análises foram ajustadas por sexo (alfa de 5\%). 0 polimorfismo rs9340799 em ESR1 foi o genótipo menos comum associado com altos níveis de cálcio $(p=0,03)$. 0 alelo menos comum em ESR1 rs1884051 foi associado com baixos níveis de fósforo $(p=0,005)$ e houve um excesso de heterozigotos para miRNA17 rs4284505 entre os indivíduos com baixos níveis de cálcio salivar $(p=0,002)$, ambos ajustados pelo sexo. Este estudo fornece evidências de que polimorfismos genéticos em ESR1 e miRNA17 estão envolvidos na determinação dos níveis de cálcio e fósforo salivares.

\section{Acknowledgements}

This work was supported by The São Paulo Research Foundation (FAPESP) (Grant number: ECK 2015/06866-5 and 2016/08149-1). Special thanks to the São Paulo Research Foundation (FAPESP) and the Coordination for the Improvement of Higher Level Personnel (CAPES), for the individual scholarships provided.

\section{References}

1. Heldring N, Pike A, Andersson S, Matthews J, Cheng G, Hartman J, et al. Estrogen receptors: how do they signal and what are their targets. Physiol Rev 2007;87:905-931.

2. Bansal N, Katz R, de Boer IH, Kestenbaum B, Siscovick DS, Hoofnagle $A N$, et al. Influence of estrogen therapy on calcium, phosphorus, and other regulatory hormones in postmenopausal women: the MESA study. J Clin Endocrinol Metab 2013;98:4890-4898.

3. Gallagher JC, Riggs BL, DeLuca HF. Effect of estrogen on calcium absorption and serum vitamin D metabolites in postmenopausal osteoporosis. J Clin Endocrinol Metab 1980;51:1359-1364.

4. Prince RL, Dick I. Oestrogen effects on calcium membrane transport: a new view of the inter-relationship between oestrogen deficiency and age-related osteoporosis. Osteoporos Int 1997;7:150-154.

5. Leimola-Virtanen $\mathrm{R}$, Helenius $\mathrm{H}$, Laine M. Hormone replacement therapy and some salivary antimicrobial factors in post- and perimenopausal women. Maturitas 1997;27:41-45.

6. Leimola-Virtanen R, Salo T, Toikkanen S, Pulkkinen J, Syrjänen S. Expression of estrogen receptor (ER) in oral mucosa and salivary glands. Maturitas 1997;31:131-137.

7. Humphrey SP, Williamson RT. A review of saliva: normal composition, flow, and function. J. Prosthet. Dent 2001;85:162-169.

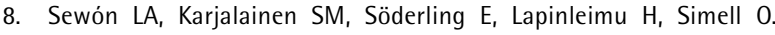


Associations between salivary calcium and oral health. J Clin Periodontol 1998;25:915-919.

9. Fiyaz M, Ramesh A, Ramalingam K, Thomas B, Shetty S, Prakash P. Association of salivary calcium, phosphate, $\mathrm{pH}$ and flow rate on oral health: A study on 90 subject. Indian Soc Periodontol 2013;17:454460.

10. Klinge CM. miRNAs and estrogen action. Trends Endocrinol Metab 2012;23:223-233.

11. Küchler EC, Pecharki GD, Castro ML, Ramos J, Barbosa F Jr, Brancher JA, et al. Genes involved in the enamel development are associated with calcium and phosphorus level in saliva. Caries Res 2017;51:225-230.

12. Aidar $M$, Line SRP. A simple and cost-effective protocol for DNA isolation from buccal epithelial cells. Braz Dent J 2007;18:148-152.

13. Purcell S, Neale B, Todd-Brown K, Thomas L, Ferreira MAR, Bender D, et al. PLINK: a toolset for whole-genome association and populationbased linkage analysis. Am J Hum Gen 2007;81.

14. Santhosh BP, Jethmalani P, Shashibhushan KK, Subba Reddy W. Effect of casein phosphopeptide-amorphous calcium phosphate containing chewing gum on salivary concentration of calcium and phosphorus: an in-vivo study. J Indian Soc Pedod Prev Dent 2012;30:146-150.

15. Weber ML, Hsin HY, Kalay E, BroŽková DS, Shimizu T, Bayram $M$, et al. Role of estrogen related receptor beta (ESRRB) in DFN35B hearing impairment and dental decay. BMC Med Genet $2014 ; 15 ; 15: 81$

16. Lago ML, Oliveira AE, Lopes FF, Ferreira EB, Rodrigues VP, Brito LM. The influence of hormone replacement therapy on the salivary flow of post-menopausal women. Gynecol Endocrinol 2015;31:109-112.

17. Liu S, Niu K, Da Y, Liu Y, Zhang J, Wang W, et al. Effects of standardized isopropanolic black cohosh and estrogen on salivary function in ovariectomized rats. Biomedicine \& Pharmacotherapy 2018;97:14381444.

18. Välimaa H, Savolainen $S$, Soukka T, SilvoniemT, Mäkelä S, Kujari H, et al. Estrogen receptor $\beta$ is the predominant estrogen receptor subtype in human oral epithelium and salivary glands. J End 2004;180:55-62.

19. Cardoso CC, Ricardo VP, Frussa-Filho R, Porto CS, Abdalla FM. Effects of $17 \beta$-estradiol on expression of muscarinic acetylcholine receptor subtypes and estrogen receptor alpha in rat hippocampus. Eur J Pharmacol 2010;634:192-200.

20. Knox SM, Lombaert IM, Reed X, Vitale-Cross L, Gutkind JS, Hoffman MP. Parasympathetic innervation maintains epithelial progenitor cells during salivary organogenesis. Science 2010;329:1645-1647.

21. Kraaij S, Brand HS, Van der Meij EH, Visscher JG. Biochemical composition of salivary stones in relation to stone and patient-related factors. Med Oral Patol Oral Cir Bucal 2018;1:23:e540-544.

22. Gilad S, Meiri E, Yogev $Y$, Benjamin S, Lebanony D, Yerushalmi N et al. Serum MicroRNAs are promising novel biomarkers. PLoS One 2008;3:e3148. 